\title{
Inotuzumab ozogamycyny w leczeniu chorych na ostrą białaczkę limfoblastyczną
}

\author{
Inotuzumab ozogamycin in the treatment of patients \\ with acute lymphoblastic leukemia
}

\author{
Aleksandra Gołos, Joanna Góra-Tybor \\ Klinika Hematologii, Instytut Hematologii i Transfuzjologii, Warszawa
}

\begin{abstract}
Streszczenie
Ostra biataczka limfoblastyczna (ALL) stanowi okoto $20 \%$ wszystkich biataczek u dorostych. Mimo wysokich odsetków catkowitych remisji (CR) po chemioterapii pierwszej linii, wyleczenie możliwe jest tylko u 30-40\% chorych. Rokowanie w przypadku nawrotu/oporności choroby jest bardzo zte, z 5-letnim czasem przezycia catkowitego (OS) wynoszacym zaledwie 7-10\%. W ostatnich latach podejmuje sie próby leczenia celowanego chorych na ALL za pomoca przeciwciat monoklonalnych skierowanych przeciwko antygenom charakterystycznym dla biataczkowych limfoblastów. Inotuzumab ozogamycyny jest humanizowanym przeciwciatem anty-CD22 skojarzonym z lekiem alkilujacym - kalicheamycyna. Lek zarejestrowano w leczeniu opornych/nawrotowych postaci ALL u dorostych na podstawie randomizowanego badania III fazy INO-VATE, w którym porównywano skuteczność inotuzumabu $i$ standardowej chemioterapii u chorych na nawrotowa/oporna ALL. W badaniu tym obserwowano znamiennie wyższe odsetki CR, dtuższy czas do progresji oraz dtuższe OS $w$ grupie pacjentów leczonych inotuzumabem. Ponadto $w$ grupie tej istotnie większy odsetek chorych poddano przeszczepieniu allogenicznych krwiotwórczych komórek macierzystych (allo-HSCT). Najczestszymi dziataniami niepożadanymi stosowania inotuzumabu byly neutropenia i matoplytkowość. Spośród powiktań niehematologicznych najistotniejsze stanowiła żylno-okluzyjna choroba watroby, której czestość wzrastała zwtaszcza u chorych poddawanych allo-HSCT. W artykule omówiono najistotniejsze badania kliniczne z zastosowaniem inotuzumabu ozogamycyny w leczeniu chorych na ALL oraz toksyczność leku.
\end{abstract}

Słowa kluczowe: inotuzumab ozogamycyny, ostra białaczka limfoblastyczna, VOD

Hematologia 2018; 9, 4: 297-305

\begin{abstract}
Acute lymphoblastic leukemia (ALL) comprises about $20 \%$ of leukemias in adult. Though the high complete remission (CR) rates after the first-line chemotherapy, only 30-40\% of ALL patients may be cured. The prognosis of relapsed/refractory ALL remains poor. The 5-year overall survival (OS) rate is $7-10 \%$. In recent years, new therapies utilizing monoclonal antibodies have been investigated. Inotuzumab ozogamycin is a humanized anti-CD22 antibody conjugated to an alkylating agent - calicheamicin. The drug was registered for relapsed/refractory ALL in adults based on INO-VATE trial, a phase III trial comparing efficacy of inotuzumab ozogamycin to chemotherapy. $C R$ rates, progression-free survival, and OS were significantly higher in the inotuzumab group.
\end{abstract}

Adres do korespondencji: Aleksandra Gołos, Klinika Hematologii, Instytut Hematologii i Transfuzjologii, ul. Indiry Gandhi 14, 02-776 Warszawa, e-mail: alexandra_golos@tlen.pl 
In addition, significantly more patients from the inotuzumab group were treated with allogeneic hematopoietic stem cell transplantation (allo-HSCT). The most common adverse events were neutropenia and thrombocytopenia. Among the non-hematological adverse events the veno-occlusive disease (VOD) was the most dangerous. The frequency of VOD increased in patients who underwent allo-HSCT. This article presents the most important clinical trials with inotuzumab ozogamycin and the toxicity of the drug.

Key words: inotuzumab ozogamycin, acute lymphoblastic leukemia, VOD

Hematologia 2018; 9, 4: 297-305

\section{Wprowadzenie}

Ostra białaczka limfoblastyczna (ALL, acute lymphoblastic leukemia) stanowi około $20 \%$ białaczek u dorosłych [1]. Stosowanie wielolekowych schematów leczenia pozwala uzyskać około $80 \%$ całkowitych remisji (CR, complete remission), jednak wysoki odsetek wznów (40-50\%) powoduje, że wyleczenie możliwe jest tylko u około $30 \%$ chorych [2]. Rokowanie u chorych ze wznową lub opornością na leczenie jest bardzo złe. Standardowa chemioterapia umożliwia osiągnięcie $\mathrm{CR}$ jedynie u 30-40\% chorych w pierwszym nawrocie i zaledwie $10-20 \%$ w kolejnych. Wśród chorych na nawrotowa/oporną ALL 5-letni czas przeżycia całkowitego (OS, overall survival) osiąga zaledwie 7-10\% leczonych [3]. Dotychczas nie ma standardów leczenia nawrotowych postaci ALL $z$ wykorzystaniem chemioterapii. Niezależnie od zastosowanego leczenia powinno ono doprowadzić do uzyskania kolejnej CR i umożliwić jak najszybsze wykonanie przeszczepienia allogenicznych krwiotwórczych komórek macierzystych (allo-HSCT, allogeneic hematopoietic stem cell transplantation). W ostatnich latach istotną rolę w leczeniu chorych na ALL, również postaci nawrotowych i opornych, zaczęła odgrywać immunoterapia oparta na przeciwciałach, takich jak blinatumomab, inotuzumab, a także chimerycznym receptorze antygenu limfocytu T (CAR-T, chimeric antigen receptor $T$-cell). Zastosowanie tych metod leczenia umożliwia uzyskanie CR i przeprowadzenie allo-HSCT u większego odsetka chorych niż standardowa chemioterapia $[4,5]$. Blinatumomab jest bispecyficznym przeciwciałem złożonym $z$ dwóch pojedynczych łańcuchów przeciwciał - anty-CD19 i anty-CD3 [6]. Dodatkowy łańcuch przeciwko CD3 aktywuje cytotoksyczne limfocyty T (CD3+), które niszczą białaczkowe limfocyty B z ekspresją antygenu CD19. Blinatumomab zarejestrowano do leczenia chorych na nawrotową i oporną ALL B-komórkową. W randomizowanym badaniu III fazy porównywano skuteczność blinatutmumabu $\mathrm{z}$ chemioterapią $\mathrm{u}$ chorych na nawrotową/oporną postać ALL, w tym $z$ nawrotem po allo-HSCT [7]. W grupie leczonej blinatumomabem OS było istotnie dłuższe niż w grupie poddanej chemioterapii $(7,7$ v. 4 miesiące; $\mathrm{p}=0,01)$. Istotnie wyższy był również odsetek $\mathrm{CR}$ i wynosił $34 \% \mathrm{w}$ porównaniu z 16\% po chemioterapii $(\mathrm{p}<0,001)$ [7]. Terapia za pomocą CAR-T polega na modyfikacji receptorów autologicznych limfocytów T tak, by rozpoznawały one antygen CD19 zlokalizowany na komórkach ALL [8]. Tak zmodyfikowane limfocyty ponownie podaje się choremu. Pierwsze badania obejmowały dorosłych i dzieci z nawrotową/oporną ALL. Odsetek uzyskanych CR wynosił ponad $70 \%$ w ciagu 28 dni $[8,9]$. W kolejnych badaniach potwierdzano tak wysokie odsetki odpowiedzi zarówno u dzieci, jak i u dorosłych $[10,11]$. Terapię CAR-T zarejestrowano w leczeniu dzieci i młodych dorosłych $\mathrm{w}$ wieku do 25 lat $\mathrm{z}$ B-komórkową ALL w nawrocie choroby po transplantacji szpiku lub w drugim bądź kolejnym rzucie leczenia. Dodatkowo rejestracją objęto nawrotowe lub oporne na co najmniej dwie linie leczenia chłoniaki rozlane $z$ dużych komórek B (DLBCL, diffuse large B-cell lymphoma) [12].

Antygen CD22 występuje na powierzchni komórek B u ponad 90\% chorych na ALL [13]. $Z$ tego powodu cząsteczka CD22 stała się ważnym celem terapeutycznym immunoterapii w ALL. Inotuzumab ozogamycyny jest bispecyficznym przeciwciałem anty-CD22 skojarzonym $z$ lekiem alkilującym - kalicheamycyną. Lek zarejestrowała zarówno amerykańska Agencja ds. Żywności i Leków (FDA, American Food and Drug Administration), jak i Europejska Agencja Leków (EMA, European Medicine Agency) do leczenia w monoterapii dorosłych pacjentów $z$ nawrotową i oporną postacią ALL [14, 15].

$\mathrm{W}$ artykule omówiono najistotniejsze badania kliniczne $z$ zastosowaniem inotuzumabu ozogamycyny w leczeniu chorych na ALL oraz toksyczność leku, ze szczególnym uwzględnieniem toksyczności wątrobowej. 


\section{Budowa, mechanizm działania, właściwości farmakokinetyczne i farmakodynamiczne inotuzumabu ozogamycyny}

\section{Budowa cząsteczki}

Inotuzumab ozogamycyny jest koniugatem przeciwciało-lek (ADC, antibody-drug coniugate) składającym się $z$ rekombinowanego humanizowanego przeciwciała monoklonalnego IgG4 kappa skierowanego przeciwko antygenowi CD22 (wytworzonego w komórkach jajnika chomika chińskiego metodą rekombinacji DNA), które jest kowalencyjnie związane $z$ dimetylohydrazydem $\mathrm{N}$-acetylo-gammakalicheamycyny (CalichDMH, calicheamicin dimethyl hydrazide) [16]. Cząsteczka CD22 jest sialoglikoproteiną o masie cząsteczkowej $135 \mathrm{kDa}$ należącą do rodziny immunoglobulin; CD22 ulega ekspresji na komórkach pro-B oraz pre-B. Jej ekspresja wzrasta na początkowych etapach dojrzewania limfocytów $B$, natomiast zanika na w pełni dojrzałych komórkach i komórkach plazmatycznych. Komórki prekursorowe limfocytów oraz komórki B pamięci nie wykazują ekspresji CD22 [17]. Po związaniu ligandu zostają uaktywnione szlaki sygnałowe kontrolujące między innymi migrację, adhezję czy przeżycie limfocytów B [17]. Kalicheamycyna jest lekiem alkilującym produkowanym przez grzyby $z$ gatunku Micromonospora echinospora [18]. W badaniach przedklinicznych na modelach ALL i chłoniaków nie-Hodgkina (NHL, non-Hodgkin lymphoma) inotuzumab ozogamycyny wykazywał 39-krotnie silniejsze działanie niż niesprzężona kalicheamycyna [19]. Średnia dawka kalicheamycyny $\mathrm{w}$ inotuzumabie ozogamycyny wynosi $5-6$ moli kalicheamycyny/mol. Przeciwciało monoklonalne rozpoznaje i przyłącza się do cząsteczki CD22 na powierzchni komórki, po czym ulega internalizacji, a następnie dezintegracji. Powoduje to uwolnienie kalicheamycyny wewnątrz komórki. Lek wiąże się z DNA i uszkadza go poprzez rozkład dwuniciowej struktury [20]. Kalicheamycyna powoduje więc apoptozę komórki w mechanizmie niezależnym od cyklu komórkowego [20].

\section{Właściwości farmakokinetyczne i farmakodynamiczne}

Kalicheamycyna w $97 \%$ wiąże się z białkami osocza. W warunkach in vitro jest ona substratem glikoproteiny P (P-gp). Metabolizm leku zachodzi w wyniku redukcji nieenzymatycznej [16]. U chorych na nawrotową lub oporną na leczenie ALL leczonych inotuzumabem ozogamycyny w za- lecanej dawce początkowej $1,8 \mathrm{mg} / \mathrm{m}^{2}$ powierzchni ciała (BSA, body surface area)/cykl ekspozycję $\mathrm{w}$ stanie stacjonarnym osiagano przed cyklem czwartym [16]. Na podstawie badań farmakokinetycznych przeprowadzonych u 234 chorych, przy dawkowaniu $1,8 \mathrm{mg} / \mathrm{m}^{2} / \mathrm{cykl} \mathrm{w}$ trzech dawkach podzielonych, biologiczny okres póttrwania pod koniec czwartego cyklu wynosił około 12 dni [16]. Zarówno w badaniach na zwierzętach, jak i na liniach komórkowych ALL inotuzumab ozogamycyny wykazywał toksyczność zależną od dawki [21]. Skuteczność leku nie zależała od poziomu ekspresji CD22 na komórkach ALL, tylko od wrażliwości komórek na kalicheamycynę oraz od ich zdolności do internalizowania kompleksu przeciwciało-lek [21]. Na liniach komórkowych ALL dowiedziono ponadto, że ciagła ekspozycja na lek cechowała się większą skutecznością $\mathrm{w}$ indukowaniu apoptozy niż dawkowanie w bolusach [22]. Wyniki te stały się przesłanką do frakcjonowanego dawkowania leku w badaniach klinicznych. $Z$ kolei w analizach farmakokinetycznych ekspozycja/dostępność inotuzumabu ozogamycyny ściśle korelowała z BSA, dlatego dawkę leku oblicza się na jej podstawie [16]. W badaniach farmakokinetycznych nie stwierdzono istotnego zmniejszenia klirensu leku u chorych $\mathrm{z}$ upośledzoną czynnością wątroby lub nerek, aczkolwiek nie prowadzono badań tylko w takich populacjach chorych [16]. Brakuje również danych dotyczących bezpieczeństwa stosowania inotuzumabu ozogamycyny w odniesieniu do schyłkowej niewydolności nerek [16].

\section{Badania kliniczne $\mathrm{z}$ zastosowaniem inotuzumabu ozogamycyny}

\section{Badania I fazy}

Badaniem I fazy objęto 79 chorych $z$ nawrotowymi/opornymi NHL, głównie $z$ chłoniakiem grudkowym (FL, follicular lymphoma) i DLBCL [23]. Mediana wieku chorych wynosiła 60 lat. Większość chorych poddano wcześniej co najmniej kilku liniom leczenia. Celem badania było określenie maksymalnej tolerowanej dawki (MTD, maximum tolerated dose), bezpieczeństwa oraz skuteczności inotuzumabu ozogamycyny. Eskalację dawek rozpoczynano od $0,4 \mathrm{mg} / \mathrm{m}^{2}$ i kończono na $2,4 \mathrm{mg} / \mathrm{m}^{2}$ $\mathrm{w}$ cyklach 3-tygodniowych. $\mathrm{W}$ przypadku stosowania dawki $2,4 \mathrm{mg} / \mathrm{m}^{2}$ u 2 chorych rozwinęła się toksyczność hematologiczna 4. stopnia (małopłytkowość i neutropenia). Na tej podstawie MTD ustalono na poziomie $1,8 \mathrm{mg} / \mathrm{m}^{2}$. Ze względu na częste wydłużenia odstępów między podawaniem kolejnych dawek leku, głównie $z$ powodu małopłytkowości, odstępy te zwiększono do 4 tygodni. Najczęstszymi działaniami niepożądanymi leku 
były małopłytkowość (90\% chorych), osłabienie (67\%), nudności $(51 \%)$ oraz neutropenia (51\%). Całkowity odsetek odpowiedzi (ORR, overall response rate) wyniósł $68 \%$ u chorych na FL i $16 \%$ $\mathrm{u}$ chorych na DLBCL. Czas wolny od progresji (PFS, progression-free survival) choroby wynosił odpowiednio 10,4 miesiąca i 49 dni [23].

Kolejne badanie polegało na skojarzeniu inotuzumabu ozogamycyny $z$ immunochemioterapią według schematu R-COP (rytuksymab, cyklofosfamid, winkrystyna, prednizon) u chorych na nawrotowe/ /oporne NHL leczonych wcześniej nie więcej niż dwoma schematami chemioterapii [19]. Do badania włączono 48 chorych. Inotuzumab ozogamycyny podawano co 21 dni w dawkach zwiększanych od $0,8 \mathrm{mg} / \mathrm{m}^{2}$ do $1,3 \mathrm{mg} / \mathrm{m}^{2}$. Maksymalna tolerowana dawka w skojarzeniu $z$ R-COP wyniosła $0,8 \mathrm{mg} /$ $/ \mathrm{m}^{2}$. Odpowiedź osiaggnięto $\mathrm{u}$ wszystkich chorych na chłoniaki indolentne i u 57\% na chłoniaki agresywne. U 24\% chorych obserwowano CR [19].

\section{Badania II fazy}

W wieloośrodkowym badaniu I/II fazy wzięło udział łącznie 72 pacjentów $\mathrm{z}$ nawrotową/oporną postacią ALL po przebyciu co najmniej jednego schematu leczenia ratunkowego. Dwadzieścia dwa procent stanowili chorzy na ALL-Filadelfia-dodatnią (Philadelphia-positive $[\mathrm{Ph}+]), 32 \%$ wszystkich pacjentów poddano wcześniej procedurze allo-HSCT [24]. W I fazie badania inotuzumab ozogamycyny otrzymało 24 chorych w następujących dawkach: $1,2 \mathrm{mg} / \mathrm{m}^{2}$ (3 chorych), $1,6 \mathrm{mg} / \mathrm{m}^{2}$ (12 chorych) i $1,8 \mathrm{mg} / \mathrm{m}^{2}$ (9 chorych) w dniach 1., 8. i 15. każdego 21-dniowego cyklu. Maksymalna liczba cykli leczenia wynosiła 6 . Na podstawie wyników I fazy badania dawkę leku ustalono na $1,8 \mathrm{mg} / \mathrm{m}^{2} /$ cykl, co potwierdzono $\mathrm{w}$ dodatkowej 12-osobowej grupie chorych. Po uzyskaniu $\mathrm{CR} / \mathrm{CR}$ bez pełnej regeneracji (CRi, complete remission with incomplete hematologic recovery) dawkę leku zmniejszano do $1,6 \mathrm{mg} / \mathrm{m}^{2}$. Ogólnie $68 \%$ chorych uzyskało CR/CRi. Negatywizację choroby resztkowej (MRD, minimal residual disease) stwierdzono u $84 \%$ spośród pacjentów z CR/CRi. Mediana czasu OS wyniosła 7,4 miesiąca, zaś mediana PFS - 3,9 miesiąca [24].

$\mathrm{W}$ innym badaniu II fazy leczono łącznie 90 chorych na nawrotową/oporną postać ALL, przy czym $14 \%$ stanowiły postacie $\mathrm{Ph}(+)$ [25]. Mediana wieku wynosiła 36 lat. Siedemdziesiąt trzy procent chorych otrzymało wcześniej co najmniej dwa schematy leczenia, a u 14\% chorych doszło do wznowy po allo-HSCT. W pierwszej części badania wzięło udział 49 chorych. Inotuzumab ozogamy- cyny podawano w jednorazowej dawce $1,8 \mathrm{mg} / \mathrm{m}^{2}$ w jednogodzinnym wlewie. Długość cyklu wynosiła 21 dni. Częściowej oceny dokonywano po dwóch cyklach leczenia. Po uzyskaniu CR leczenie kontynuowano do czterech kursów; w przypadku braku odpowiedzi lub progresji choroby $(\mathrm{PD}$, progressive disease) u chorych CD20+ dołączano rytuksymab. $\mathrm{W}$ pierwszym kursie leczenia skojarzonego rytuksymab podawano $\mathrm{w}$ dawce $375 \mathrm{mg} / \mathrm{m}^{2} 1$. dnia, zaś inotuzumab -2 . dnia cyklu. W kolejnych cyklach oba leki stosowano 1 . dnia, przy czym rytuksymab podawano przed inotuzumabem. Pierwszorzędowym punktem końcowym był ORR. U $18 \%$ chorych stwierdzono CR, u 39\% CRi. Mediana czasu OS wynosiła 2,4 miesiąca u chorych bez odpowiedzi, natomiast u chorych $z \mathrm{CR} / \mathrm{CRi}-7,6$ miesiąca [25]. $\mathrm{W}$ drugiej części badania zmieniono schemat dawkowania inotuzumabu - łączną dawkę $1,8 \mathrm{mg} / \mathrm{m}^{2}$ stosowano $\mathrm{w}$ trzech dawkach podzielonych, tj. $0,8 \mathrm{mg} / \mathrm{m}^{2} 1$. dnia oraz po $0,5 \mathrm{mg} / \mathrm{m}^{2} \mathrm{w}$ dniach 8 . i 15. [26]. Długość cyklu nie uległa zmianie. Zarówno ORR, jak i OS nie różniły się istotnie w porównaniu ze schematem $z$ jednorazowym podaniem leku, natomiast stosowanie inotuzumabu w dawkach podzielonych (schemat jw.) cechowała mniejsza toksyczność wątrobowa oraz związana $z$ infuzją [26].

W badaniu Advani i wsp. [27] oceniano skuteczność inotuzumabu u 35 chorych (mediana wieku 34 lata, zakres: 20-79 lat). Siedemnaście procent chorych otrzymało wcześniej co najmniej pięć linii leczenia, 43\% było po allo-HSCT [27]. Inotuzumab ozogamycyny podawano $\mathrm{w}$ dawce $1,8 \mathrm{mg} / \mathrm{m}^{2} / \mathrm{cykl}\left(0,8 \mathrm{mg} / \mathrm{m}^{2} 1\right.$. dnia i $0,5 \mathrm{mg} / \mathrm{m}^{2}$ w dniach 8. i 15.). Cykle powtarzano co 3 tygodnie. Po uzyskaniu CR/CRi dawkę zmniejszano do $1,6 \mathrm{mg} / \mathrm{m}^{2}$. Leczenie kontynuowano do sześciu cykli. U jednego chorego obserwowano toksyczność ograniczającą dawkę (wzrost aktywności lipazy), u 5 innych chorych opóźniano lub zmniejszano dawkę leku ze względu na hepatotoksyczność (wzrost aktywności aminotransferazy asparaginianowej [AspAT, aspartate aminotransferase]). Łączny odsetek CR i CRi wyniósł 65,7\%, przy czym $78 \%$ chorych uzyskało CR MRD(-). Mediana OS sięgała 7,4 miesiąca [27]. Mediana czasu obserwacji chorych, którzy przeżyli, wynosiła 4,4 miesiąca (zakres 0,7-11 miesięcy). U 34 chorych przerwano leczenie. Główne przyczyny obejmowały: progresję choroby $\mathrm{w}$ trakcie leczenia (19), wykonanie allo-HSCT (7), działania niepożądane (5) oraz inne (3) [27].

\section{Inotuzumab w skojarzeniu $\mathrm{z}$ chemioterapią}

W badaniu II fazy przeprowadzonym przez Jabbour i wsp. [28] oceniano skuteczność i bez- 
pieczeństwo stosowania inotuzumabu ozogamycyny w połączeniu $z$ chemioterapią o zmniejszonej toksyczności. Wzięło w nim udział 59 chorych na nawrotową/oporną ALL; mediana wieku wynosiła 35 lat (zakres 18-87 lat). Pierwszorzędowym punktem końcowym było OS, a drugorzędowe punkty końcowe obejmowały: bezpieczeństwo, czas do nawrotu choroby, odsetek allo-HSCT oraz odsetek negatywizacji MRD. Inotuzumab ozogamycyny początkowo stosowano w dawce $1,8 \mathrm{mg} / \mathrm{m}^{2} 3$. dnia pierwszego cyklu, w kolejnych trzech cyklach w dawce $1,6 \mathrm{mg} / \mathrm{m}^{2}$. Cykl trwal 21 dni. $Z$ powodu wystąpienia żylno-okluzyjnej choroby wątroby (VOD, veno-occlusive disease) dawkę zmniejszono do $1,3 \mathrm{mg} / \mathrm{m}^{2} \mathrm{w} 1$. cyklu oraz do $1 \mathrm{mg} / \mathrm{m}^{2}$ w kolejnych. W nieparzystych cyklach do inotuzumabu dołączano chemioterapię według schematu minihyper-CVD $\left(150 \mathrm{mg} / \mathrm{m}^{2}\right.$ cyklofosfamidu co $12 \mathrm{~h}$ w dniach 1.-3., $20 \mathrm{mg}$ deksametazonu $\mathrm{w}$ dniach 1.-4. i 11.-14., 2 mg winkrystyny w dniach 1 . i 8.). W cyklach parzystych stosowano metotreksat $\mathrm{w}$ dawce $250 \mathrm{mg} / \mathrm{m}^{2} 1$. dnia oraz arabinozyd cytozyny w dawce $0,5 \mathrm{mg} / \mathrm{m}^{2}$ co 12 godzin w dniach 2 . i 3 . U 46 chorych (78\%) obserwowano odpowiedź na leczenie, 35 (59\%) osiągnęło CR, a u 82\% spośród $z$ nich stwierdzono negatywizację MRD. U 26 pacjentów wykonano allo-HSCT. Najczęstszymi działaniami niepożądanymi o 3. i 4. stopniu nasilenia były przedłużająca się trombocytopenia (81\%), infekcje (73\%) i hiperbilirubinemia (14\%). U 9 chorych (15\%) wystąpiła VOD. Mediana czasu obserwacji wynosiła 24 miesiące, zaś mediany czasu do nawrotu choroby i OS - odpowiednio 8 i 11 miesięcy. Odsetki rocznego OS u chorych $\mathrm{w}$ pierwszym, drugim i trzecim lub kolejnym nawrocie wyniosły odpowiednio 57\%, 26\% i 39\% [28].

W podobnym badaniu II fazy oceniano skuteczność inotuzumabu w połączeniu $z$ chemioterapią $\mathrm{u}$ chorych po 60 . roku życia $z$ nowo rozpoznaną ALL [29]. Do badania włączono 52 pacjentów $z$ medianą wieku 68 lat (zakres 64-72 lata). Mediana czasu obserwacji wyniosła 29 miesięcy (zakres 13-48). Inotuzumab podawano 3 . dnia w pierwszym cyklu w dawce $1,3-1,8 \mathrm{mg} / \mathrm{m}^{2}$, natomiast w następnych cyklach w dawce $1,0-1,3 \mathrm{mg} / \mathrm{m}^{2}$. Schematy i dawki chemioterapii były takie same jak w badaniu Jabbour i wsp. [28]. Dwuletnie PFS wynosiło $59 \%$. Najczęstszymi działaniami niepożądanymi były przedłużająca się małopłytkowość (81\% chorych), infekcje (52\% w okresie indukcji, 36\% w konsolidacji), hiperglikemia (54\%), hipokaliemia (31\%), zwiększona aktywność aminotransferaz (19\%), hiperbilirubinemia (17\%) oraz krwawienia (15\%). Żylno-okluzyjną chorobę wątroby obserwowano u 4 (8\%) chorych. Sześciu chorych (12\%) zmarło $z$ powodu działań niepożądanych; $5(10 \%)$ z powodu posocznicy oraz $1(2 \%)$ z powodu VOD [29].

\section{Badanie III fazy INO-VATE}

W randomizowanym badaniu III fazy INO-VATE (INotuzumab Ozogamicin trial to inVestigAte Tolerability and Efficacy) porównywano skuteczność inotuzumabu i standardowej chemioterapii u chorych na oporną/nawrotową ALL [30]. Do badania włączono 326 chorych, którzy ukończyli 18. rok życia, po jednej lub dwóch liniach terapii, u których stwierdzono co najmniej $5 \%$ limfoblastów w szpiku oraz ekspresję CD22 na blastach. Randomizację prowadzono zależnie od długości trwania pierwszej remisji $(<12$ $v . \geq 12$ miesiące), liczby linii leczenia i wieku ( $<55 v$. $\geq 55$ lat). Pierwszorzędowymi celami badania były odsetek pacjentów w CR/CRi oraz OS. Cele drugorzędowe stanowiły bezpieczeństwo, długość trwania remisji, PFS, odsetek pacjentów poddanych allo-HSCT odsetek negatywizacji MRD. $\mathrm{W}$ badaniu nie dopuszczano zamiany grup.

Inotuzumab stosowano w dawce początkowej $1,8 \mathrm{mg} / \mathrm{m}^{2} / 21$-dniowy cykl $\left(0,8 \mathrm{mg} / \mathrm{m}^{2} 1\right.$. dnia; $0,5 \mathrm{mg} /$ $/ \mathrm{m}^{2} \mathrm{w}$ dniach 8. i 15.). Po osiągnięciu CR lub CRi dawkę leku 1 . dnia zmniejszano do $0,5 \mathrm{mg} / \mathrm{m}^{2}$. Maksymalna liczba cykli inotuzumabu wynosiła sześć. W grupie kontrolnej pacjenci, zależnie od wyboru badacza, otrzymywali schemat FLAG (cytarabina, fludarabina, czynnik stymulujący tworzenie kolonii granulocytów [G-CSF, granulocyte-specific colony-stimulating factor]), cytarabinę i mitoksantron lub duże dawki cytarabiny.

Odsetek uzyskanych $\mathrm{CR} / \mathrm{CRi}$ był istotnie wyższy w grupie chorych leczonych inotuzumabem (80,7\% [95-proc. przedział ufności $\{\mathrm{CI}$, confidence interval\}, 72-88\%] v. 29,4\% [21-39\%]; $\mathrm{p}<0,001$ ). Wyższe odsetki odpowiedzi obserwowano we wszystkich badanych grupach pacjentów, niezależnie od wieku, liczby linii leczenia, długości trwania pierwszej remisji, wyjściowego odsetka blastów we krwi obwodowej i szpiku, ekspresji CD22 na komórkach blastycznych $(\geq 90 \% v .<90 \%)$ czy wykonanego wcześniej allo-HSCT. Tylko u chorych $\mathrm{z}$ obecnością chromosomu $\mathrm{Ph}$ lub translokacji $\mathrm{t}(4 ; 11)$ nie stwierdzano różnic w odsetkach remisji $\mathrm{w}$ grupie leczonych inotuzumabem w porównaniu ze standardową chemioterapią.

U większości chorych w obu grupach odpowiedź obserwowano już po pierwszym cyklu terapii. U pacjentów $z \mathrm{CR} / \mathrm{CRi}$ negatywizację MRD stwierdzano istotnie częściej w grupie leczonej inotuzumabem (78,4\% [95\% CI, 68-87\%] v. 28,1\% 
[14-47\%]; $\mathrm{p}<0,001)$. Czas trwania CR/CRi był dłuższy w grupie chorych leczonych inotuzumabem niż w grupie kontrolnej i wynosił odpowiednio 4,6 $(3,9-5,4)$ w porównaniu z 3,1 $(1,4-4,9)$ miesiąca (współczynnik ryzyka [HR, hazard ratio] [95\% $\mathrm{CI}], 0,55[0,31-0,96] ; \mathrm{p}=0,03)$. W grupie leczonej inotuzumabem istotnie więcej chorych było poddanych allo-HSCT ( $41 \%$ v. $11 \%$; $\mathrm{p}<0,001)$. $\mathrm{U}$ chorych leczonych inotuzumabem PFS było istotnie dłuższe (HR 0,45 [97,5\% CI, 0,34-0,61]; $\mathrm{p}<0,001)$, mediany PFS wynosiły odpowiednio 5 (95\% CI, 3,7-5,6) w porównaniu z 1,8 [95\% CI, 1,5-2,2] miesiąca. Mediana OS u pacjentów leczonych inotuzumabem wynosiła 7,7 miesiąca $(95 \%$ CI, 6,0-9,2), zaś w grupie poddanej standardowej chemioterapii - 6,7 miesiąca [4,9-8,3], natomiast 2-letnie OS wynosiło odpowiednio 23\% (95\% CI, 16-30\%) w porównaniu z 10\% (5-16\%).

Jabbour i wsp. [31] opublikowali wyniki subanalizy służącej porównaniu wyników terapii w grupie chorych ponizej 55 lat i starszych. Odsetki $\mathrm{CR} / \mathrm{CRi}$, czas trwania odpowiedzi i PFS były podobne w obu grupach, natomiast mediana OS była krótsza w grupie starszych chorych $(5,6 v$. 8,6 miesiąca, HR 0,61) [31]. Subanaliza badania INO-VATE dotycząca OS dostosowanego do jakości życia (QALY, quality-adjusted life years) wykazała, $\dot{z}$ e terapia inotuzumabem ozogamycyny pozwala uzyskać około 2 QALY w porównaniu ze standardową chemioterapią [32]. Szacowana długość QALY wynikała $z$ wyższych odsetków uzyskanych CR i przeprowadzenia allo-HSCT u większej liczby pacjentów z grupy leczonej inotuzumabem [32].

Najczęstszymi objawami niepożądanymi w obu badanych grupach były cytopenie. Małopłytkowość co najmniej 3. stopnia obserwowano u $37 \%$ chorych leczonych inotuzumabem i u $59 \%$ poddanych standardowej chemioterapii. Gorączka neutropeniczna 3. lub wyższego stopnia również rzadziej występowała u chorych leczonych inotuzumabem, odpowiednio $24 \%$ w porównaniu z $49 \%$.

U chorych leczonych inotuzumabem częściej obserwowano toksyczność wątrobową. Podwyższoną aktywność AspAT oraz aminotransferazy alaninowej (AlAT, alanine aminotransferase) i hiperbilirubinemię obserwowano odpowiednio u $20 \%, 14 \%$ i $15 \%$ chorych otrzymujących inotuzumab oraz $10 \%, 11 \%$ i $10 \%$ chorych poddanych standardowej chemioterapii. U chorych leczonych inotuzumabem istotnie częściej obserwowano VOD $(11 \%[\mathrm{n}=15]$ v. $1 \%[\mathrm{n}=1])$. Spośród 15 pacjentów leczonych inotuzumabem, u których wystąpiła VOD, u 5 powikłanie to wystąpiło w trakcie leczenia lub wkrótce po jego zakończeniu (2 chorych w tej grupie wcześniej było leczonych allo-HSCT), natomiast u 10 pacjentów VOD rozwinęła się po allo-HSCT (dla 3 chorych było to 2 . procedura allo-HSCT). Żylno-okluzyjna choroba wątroby rozwijała się po medianie czasu 16 dni (3-39 dni) po transplantacji. W analizie wielowariancyjnej jako jedyny czynnik sprzyjający VOD po transplantacji zidentyfikowano zastosowanie dwóch leków alkilujących w schemacie kondycjonującym.

Zestawienie najważniejszych badań klinicznych $\mathrm{z}$ zastosowaniem inotuzumabu przedstawiono w tabeli 1 .

\section{Działania niepożądane}

Wyniki badań I/II fazy oraz badania INO-VATE wskazują, że najczęstszym działaniem niepożądanym związanym ze stosowaniem inotuzumabu były cytopenie [24, 26, 30]. Małopłytkowość co najmniej

Tabela 1. Najważniejsze badania kliniczne z zastosowaniem inotuzumabu ozogamycyny u chorych na nawrotową/oporną ostrą białaczką limfoblastyczną

Table 1. Key clinical trials of inotuzumab ozogamicin in patients with relapsed/refractory acute lymphoblastic leukemia

\begin{tabular}{|c|c|c|c|c|c|}
\hline Autor & $\begin{array}{c}\text { Faza } \\
\text { badania }\end{array}$ & $\begin{array}{l}\text { Liczba } \\
\text { chorych }\end{array}$ & Dawkowanie inotuzumabu & ORR (\%) & $\begin{array}{c}\text { Mediana OS } \\
\text { (miesiące) }\end{array}$ \\
\hline DeAngelo i wsp. [24] & $1 / I I$ & 72 & $\begin{array}{c}0,8 \mathrm{mg} / \mathrm{m}^{2} \text { 1. dnia, } \\
0,5 \mathrm{mg} / \mathrm{m}^{2} \text { 8. i 15. dnia }\end{array}$ & 68 & 7,4 \\
\hline Kantarjian i wsp. [25] & II & 49 & $1,8 \mathrm{mg} / \mathrm{m}^{2} 1$. dnia & 57 & 7,6 \\
\hline Kantarjian i wsp. [26] & II & 41 & $\begin{array}{c}0,8 \mathrm{mg} / \mathrm{m}^{2} \text { 1. dnia, } \\
0,5 \mathrm{mg} / \mathrm{m}^{2} \text { 8. i 15. dnia }\end{array}$ & 59 & 7,3 \\
\hline Advani i wsp. [27] & II & 35 & $\begin{array}{c}0,8 \mathrm{mg} / \mathrm{m}^{2} \text { 1. dnia, } \\
0,5 \mathrm{mg} / \mathrm{m}^{2} \text { 8. i 15. dnia }\end{array}$ & 65,7 & 7,4 \\
\hline Kantarjian i wsp. [30] & III & 326 & $\begin{array}{c}0,8 \mathrm{mg} / \mathrm{m} 2 \text { 1. dnia, } \\
0,5 \mathrm{mg} / \mathrm{m}^{2} \text { 8. i 15. dnia }\end{array}$ & 80,7 & 7,7 \\
\hline
\end{tabular}

ORR (overall response rate) — całkowity odsetek odpowiedzi; OS (overall survival) — przeżycie całkowite 
3. stopnia obserwowano u około $35 \%$ leczonych chorych, neutropenię co najmniej 3. stopnia u około $30 \%$, a niedokrwistość u $20 \%$ chorych $[24,26,30]$.

Najczęstszymi niehematologicznymi objawami niepożądanymi stosowania inotuzumabu obserwowanymi w badaniu INO-VATE były nudności (32\%), bóle głowy (28\%) i gorączka (27\%), występujące zazwyczaj w stopniach 1. i 2. [24, 26, 30]. Rzadko obserwowano reakcje związane $z$ podaniem leku (1\%) czy wydłużenie odcinka QT w elektrokardiogramie $(2 \%)$.

Najistotniejszym klinicznie działaniem niepożądanym inotuzumabu jest toksyczność wątrobowa, a przede wszystkim zwiększona częstość występowania VOD. W 2017 roku w „Lancet Hematology” opublikowano analizę Assi i wsp. [33] dotyczącą hepatotoksyczności inotuzumabu obserwowanej w badaniu INO-VATE. Hepatotoksyczność związaną $z$ leczeniem obserwowano istotnie częściej u chorych leczonych inotuzumabem (51\%) niż u pacjentów poddanych standardowej chemioterapii (34\%). Częstość objawów związanych $z$ uszkodzeniem wątroby obserwowanych w badaniu INO-VATE zestawiono w tabeli 2 . Analiza jednowariancyjna wykazała, że hepatotoksyczności inotuzumabu sprzyjają wcześniejsze (przed leczeniem inotuzumabem) allo-HSCT, dwie lub więcej wcześniejszych terapii ratunkowych, dodatni wywiad w kierunku chorób wątroby, wcześniejsze uszkodzenie wątroby oraz obecność ponad 1000 blastów/ $\mu$ l we krwi obwodowej przed leczeniem. Analiza wielowariancyjna potwierdziła istotność wcześniejszego allo-HSCT, liczby blastów i obciążającego wywiadu w kierunku chorób wątroby.

Podczas leczenia i 2-letniej obserwacji VOD wystąpiła u 22 chorych (13\%) otrzymujących inotuzumab i tylko u jednego chorego $(<1 \%)$ poddanego standardowej chemioterapii. U $82 \%$ pacjentów leczonych inotuzumabem, u których obserwowano VOD, powikłanie to miało nasilenie 3. lub wyższego stopnia według CTCAE (Common Terminology Criteria for Adverse Events). U większości chorych VOD wystąpiła po allo-HSCT (u 17 po wcześniejszym leczeniu inotuzumabem i 1 chorego po standardowej chemioterapii). U 5 chorych (wszyscy leczeni wcześniej inotuzumabem) VOD była przyczyną zgonu. Mediana czasu od podania pierwszej dawki inotuzumabu do wystąpienia tej choroby wyniosła $30 \mathrm{dni}$ (14-238 dni), a od procedury allo-HSCT do wystąpienia VOD - 15 dni (10-17 dni).

Analiza jednowariancyjna dowiodła, $\dot{z}$ e ryzyko VOD istotnie wzrasta w przypadku zastosowania dwóch leków alkilujących w kondycjonowaniu (2 leki $v$. 1 lek), zastosowaniu busulfanu w kondycjonowaniu, u chorych w wieku co najmniej 55 lat, po wcześniejszym leczeniu allo-HSCT, a także u chorych, u których przed allo-HSCT stwierdzano stężenie bilirubiny równe lub powyżej górnej granicy normy. W analizie wielowariancyjnej potwierdzono istotność zastosowania dwóch leków alkilujących $\mathrm{w}$ kondycjonowaniu i stężenia bilirubiny równego

Tabela 2. Objawy hepatotoksyczności w grupie chorych leczonych inotuzumabem w porównaniu ze standardową chemioterapią w badaniu INO-VATE (źródło [23])

Table 2. Hepatotoxic events in patients treated with inotuzumab versus chemotherapy in the INO-VATE study (source [23])

\begin{tabular}{|l|c|c|c|c|}
\hline \multirow{2}{*}{ Objaw } & \multicolumn{3}{|c|}{\begin{tabular}{c} 
Leczenie \\
\cline { 2 - 5 }
\end{tabular}} & \multicolumn{2}{|c|}{$\begin{array}{c}\text { Inotuzumab } \\
\mathbf{n = 1 6 4}\end{array}$} & $\begin{array}{c}\text { Standardowa chemioterapia } \\
\mathbf{n}=\mathbf{1 4 9}\end{array}$ \\
\cline { 2 - 5 } & $\begin{array}{c}\text { Wszystkie stopnie } \\
\mathbf{n}(\%)\end{array}$ & $\begin{array}{c}\text { 3. stopień } \\
\mathbf{n}(\%)\end{array}$ & $\begin{array}{c}\text { Wszystkie stopnie } \\
\mathbf{n}(\%)\end{array}$ & $\begin{array}{c}\text { 3. stopień } \\
\mathbf{n}(\%)\end{array}$ \\
\hline Podwyższona aktywność AspAT & $37(23)$ & $7(4)$ & $16(11)$ & $5(3)$ \\
\hline Podwyższona aktywność GGTP & $35(21)$ & $18(11)$ & $12(8)$ & $7(5)$ \\
\hline Podwyższona aktywność AIAT & $25(15)$ & $6(4)$ & $18(13)$ & $7(5)$ \\
\hline Hiperbilirubinemia & $35(21)$ & $10(6)$ & $24(17)$ & $9(6)$ \\
\hline Podwyższona aktywność FA & $22(13)$ & $3(1)$ & $10(7)$ & 0 \\
\hline VOD* & $27(16)$ & $18(11)$ & $1(<1)$ & $1(<1)$ \\
\hline Hipalbuminemia & $10(6)$ & $2(1)$ & $7(5)$ & $2(1)$ \\
\hline Wodobrzusze & $(5)$ & $3(2)$ & 0 & 0 \\
\hline Hepatomegalia & $1(<1)$ & 0 & 0 & 0 \\
\hline
\end{tabular}

*VOD była przyczyną zgonu 5 chorych (5. stopień toksyczności); AspAT (aspartate aminotransferase) - aminotransferaza asparaginianowa; GGTP (gamma-glutamyl transpherase) - gammaglutamylotransferaza; AlAT (alanine aminotransferase) — aminotransferaza alaninowa; FA (alkalic phosphatase) - fosfataza alkaliczna; VOD (veno-oclusive disease) - żylno-okluzyjna choroba wątroby 
lub wyższego od górnej granicy normy przed allo-HSCT. Należy podkreślić, że ryzyko VOD po allo-HSCT zależy również od liczby wcześniej zastosowanych cykli leczenia inotuzumabem - powikłanie to obserwowano u $8 \%, 19 \%$ i $29 \%$ chorych, którzy otrzymali odpowiednio jeden, dwa i więcej niż dwa cykle leczenia [33].

W 2018 roku w „Bone Marrow Transplantation" ukazały się zalecenia ekspertów dotyczące postępowania w przypadku pojawienia się działań niepożądanych związanych $z$ inotuzumabem [34]. Szczególnie wiele miejsca poświęcono zapobieganiu VOD, która jest typowym powikłaniem wątrobowym występującym po allo-HSCT. Znane czynniki, które sprzyjają VOD, to: mieloablacyjne kondycjonowanie oparte na busulfanie, napromienianie całego ciała (TBI, total body irradiation), starszy wiek, mniej niż 90\% sprawności w skali Karnofskiego, zaawansowana choroba (przeszczepienie we wznowie lub $>2$ remisje) i aktywne wirusowe zapalenie wątroby $[35,36]$. Uważa się, że w przypadku stosowania w kondycjonowaniu leków alkilujących wystąpieniu VOD sprzyja uszkodzenie śródbłonka zatok wątrobowych powodowane przez leki $z$ tej grupy [36]. W przypadku inotuzumabu mechanizm wywoływania VOD nie jest jasny, ale — biorąc pod uwagę zwiększoną częstość tego powikłania po stosowaniu gemtuzumabu (przeciwciało monoklonalne anty-CD33 sprzężone $z$ kalicheamycyną) - można sądzić, że to właśnie kalicheamycyna, uszkadzając śródbłonek zatok wątrobowych, odpowiada za zwiększoną częstość VOD po leczeniu przeciwciałami, które są $z$ nią sprzężone [36, 37].

U chorych leczonych inotuzumabem, u których jest planowane allo-HSCT, zaleca się stosowanie maksymalnie dwóch cykli inotuzumabu, unikanie kondycjonowania zawierającego dwa leki alkilujące (np. tiotepa i melfalan) oraz, o ile to możliwe, unikanie leków hepatotoksycznych, takich jak na przykład azole. Eksperci wskazują również na zasadność profilaktycznego stosowania kwasu ursodeoksycholowego [35]. Oczywiście podstawowe znaczenie ma wczesne rozpoznanie VOD, a zatem zwrócenie uwagi na takie objawy, jak zwiększenie masy ciała, żółtaczka, powiększenie wątroby i jej bolesność, obrzęki czy wodobrzusze [35, 36].

\section{Podsumowanie}

Inotuzumab może stanowić cenną opcję terapeutyczną u pacjentów $\mathrm{z}$ oporną/nawrotową ALL. W tej grupie chorych lek powoduje istotnie więcej $\mathrm{CR} / \mathrm{CRi}$ niż standardowa chemioterapia.
Co więcej, u większości chorych, którzy osiągnęli remisję, stwierdza się ujemną MRD. Leczenie inotuzumabem może zatem pozwolić większej liczbie pacjentów $z$ oporną/nawrotową ALL na kwalifikację do allo-HSCT - jedynej opcji terapeutycznej umożliwiającej wyleczenie $\mathrm{w}$ tej grupie chorych. Należy jednak zwrócić szczególną uwagę na profil toksyczności leku, a zwłaszcza zwiększony odsetek VOD po transplantacji. Konieczne jest przestrzeganie zaleceń, takich jak ograniczenie liczby cykli inotuzumabu do dwóch, unikanie stosowania dwóch leków alkilujących w kondycjonowaniu oraz stosowanie kwasu ursodeoksycholowego u wszystkich chorych przyjmujących inotuzumab.

Inotuzumab jest zarejestrowany do leczenia chorych na oporną/nawrotową ALL. Trwają jednak badania nad skutecznością leku stosowanego $\mathrm{w}$ terapii pierwszej linii łącznie $z$ chemioterapią. Być może większy odsetek remisji MRD(-) uzyskanych dzięki zastosowaniu tego przeciwciała pozwoli na wydłużenie OS chorych na ALL.

\section{Piśmiennictwo}

1. Seferyńska I. Zachorowania na ostre białaczki szpikowe i limfoblastyczne u dorosłych w Polsce w latach 2004-2010. Hematologia. 2015; 6(B): 1-40, doi: 10.5603/Hem.2015.0044.

2. Inaba $H$, Greaves M, Mullighan CG. Acute lymphoblastic leukaemia. Lancet. 2013; 381(9881): 1943-1955, doi: 10.1016/S01406736(12)62187-4, indexed in Pubmed: 23523389.

3. Fielding AK, Richards SM, Chopra R, et al. Medical Research Council of the United Kingdom Adult ALL Working Party, Eastern Cooperative Oncology Group. Outcome of 609 adults after relapse of acute lymphoblastic leukemia (ALL); an MRC UKALL12/ /ECOG 2993 study. Blood. 2007; 109(3): 944-950, doi: 10.1182/ /blood-2006-05-018192, indexed in Pubmed: 17032921.

4. Maury S, Chevret S, Thomas X, et al. for GRAALL. Rituximab in B-lineage adult acute lymphoblastic leukemia. N Engl J Med. 2016; 375(11): 1044-1053, doi: 10.1056/NEJMoa1605085, indexed in Pubmed: 27626518.

5. Sawczuk-Chabin J, Ejduk A, Lech-Marańda E. Blinatumomab — nowy lek u chorych na nawrotową/ /oporną ostrą białaczkę limfoblastyczną. Hematologia. 2017; 7(4): 312-326, doi: 10.5603/hem.2016.0030.

6. Topp MS, Kufer P, Gökbuget N, et al. Targeted therapy with the T-cell-engaging antibody blinatumomab of chemotherapy-refractory minimal residual disease in B-lineage acute lymphoblastic leukemia patients results in high response rate and prolonged leukemia-free survival. J Clin Oncol. 2011; 29(18): 2493-2498, doi: 10.1200/JCO.2010.32.7270, indexed in Pubmed: 21576633.

7. Kantarjian H, Stein A, Gökbuget N, et al. Blinatumomab versus chemotherapy for advanced acute lymphoblastic leukemia. N Engl J Med. 2017; 376(9): 836-847, doi: 10.1056/NEJMoa1609783, indexed in Pubmed: 28249141.

8. Brentjens RJ, Rivière I, Park JH, et al. Safety and persistence of adoptively transferred autologous CD19-targeted T cells in patients with relapsed or chemotherapy refractory B-cell leukemias. Blood. 2011; 118(18): 4817-4828, doi: 10.1182/ /blood-2011-04-348540, indexed in Pubmed: 21849486. 
9. Brudno JN, Somerville RPT, Shi V, et al. Allogeneic T cells that express an anti-CD19 chimeric antigen receptor induce remissions of B-cell malignancies that progress after allogeneic hematopoietic stem-cell transplantation without causing graft-versus-host disease. J Clin Oncol. 2016; 34(10): 1112-1121, doi: 10.1200/ /JCO.2015.64.5929, indexed in Pubmed: 26811520.

10. Park JH, Rivière I, Gonen M, et al. Long-term follow-up of CD19 CAR therapy in acute lymphoblastic leukemia. N Engl J Med. 2018; 378(5): 449-459, doi: 10.1056/NEJMoa1709919, indexed in Pubmed: 29385376.

11. Gardner RA, Finney O, Annesley C, et al. Intent-to-treat leukemia remission by CD19 CAR T cells of defined formulation and dose in children and young adults. Blood. 2017; 129(25): 3322-3331, doi: 10.1182/blood-2017-02-769208, indexed in Pubmed: 28408462.

12. Agency. Kymirah EM. https:/www.ema.europa.eu/en/medicines/ /human/EPAR/kymriah (21 Dec 2018).

13. Haso W, Lee DW, Shah NN, et al. Anti-CD22-chimeric antigen receptors targeting B-cell precursor acute lymphoblastic leukemia. Blood. 2013; 121(7): 1165-1174, doi: 10.1182/ /blood-2012-06-438002, indexed in Pubmed: 23243285.

14. FDA. Besponsa U. (inotuzumab ozogamicin) for injection, for inntravenous use: US prescribing information. 2017. https://www. fda.gov/ (17 Oct 2018).

15. Agency. Besponsa EM. (inotuzumab ozogamicin): EU summary of product characteristics. 2017. https://www.ema.europa.eu/ (17 Oct 2018)

16. Besponsa. Charakterystyka produktu leczniczego 2017. https: //ec.europa.eu/health/documents/community-register/2017/ /20170629138094/anx_138094_pl.pdf (17 Oct 2018).

17. Moyron-Quiroz JE, Partida-Sánchez S, Donís-Hernández R, et al. Expression and function of $\mathrm{CD} 22$, a B-cell restricted molecule. Scand J Immunol. 2002; 55(4): 343-351, indexed in Pubmed: 11967115.

18. Hinman LM, Hamann PR, Wallace R, et al. Preparation and characterization of monoclonal antibody conjugates of the calicheamicins: a novel and potent family of antitumor antibiotics. Cancer Res. 1993; 53(14): 3336-3342, indexed in Pubmed: 8324745.

19. DiJoseph JF, Armellino DC, Boghaert ER, et al. Antibody-targeted chemotherapy with CMC-544: a CD22-targeted immunoconjugate of calicheamicin for the treatment of B-lymphoid malignancies. Blood. 2004; 103(5): 1807-1814, doi: 10.1182/ /blood-2003-07-2466, indexed in Pubmed: 14615373.

20. Shor B, Gerber HP, Sapra P. Preclinical and clinical development of inotuzumab-ozogamicin in hematological malignancies. Mol Immunol. 2015; 67(2 Pt A): 107-116, doi: 10.1016/j.molimm. 2014.09.014, indexed in Pubmed: 25304309.

21. de Vries JF, Zwaan CM, De Bie M, et al. The novel calicheamicin-conjugated CD22 antibody inotuzumab ozogamicin (CMC-544) effectively kills primary pediatric acute lymphoblastic leukemia cells. Leukemia. 2012; 26(2): 255-264, doi: 10.1038/leu.2011.206, indexed in Pubmed: 21869836.

22. Thota S, Advani A. Inotuzumab ozogamicin in relapsed B-cell acute lymphoblastic leukemia. Eur J Haematol. 2017; 98(5): 425-434, doi: 10.1111/ejh.12862, indexed in Pubmed: 28152223.

23. Advani A, Coiffier B, Czuczman MS, et al. Safety, pharmacokinetics, and preliminary clinical activity of inotuzumab ozogamicin, a novel immunoconjugate for the treatment of B-cell non-Hodgkin's lymphoma: results of a phase I study. J Clin Oncol. 2010; 28(12): 2085-2093, doi: 10.1200/JCO.2009.25.1900, indexed in Pubmed: 20308665.

24. DeAngelo DJ, Stock W, Stein AS, et al. Inotuzumab ozogamicin in adults with relapsed or refractory CD22-positive acute lympho- blastic leukemia: a phase 1/2 study. Blood Adv. 2017; 1(15): 1167-1180, doi: 10.1182/bloodadvances.2016001925, indexed in Pubmed: 29296758.

25. Kantarjian H, Thomas D, Jorgensen J, et al. Inotuzumab ozogamicin, an anti-CD22-calecheamicin conjugate, for refractory and relapsed acute lymphocytic leukaemia: a phase 2 study. Lancet Oncol. 2012; 13(4): 403-411, doi: 10.1016/s1470-2045(11)70386-2, indexed in Pubmed: 22357140.

26. Kantarjian H, Thomas D, Jorgensen J, et al. Results of inotuzumab ozogamicin, a CD22 monoclonal antibody, in refractory and relapsed acute lymphocytic leukemia. Cancer. 2013; 119(15): 2728 -2736, doi: 10.1002/cncr.28136, indexed in Pubmed: 23633004.

27. Advani AS, Stein AS, Kantarjian HM, et al. et al.. A phase II study of weekly inotuzumab ozogamicin (InO) in adult patients with CD22-positive acute lymphoblastic leukemia (ALL) in second or later salvage. Blood. 2014; 124(21): 2255-2255.

28. Jabbour E, Ravandi F, Kebriaei P, et al. Salvage chemoimmunotherapy with inotuzumab ozogamicin combined with mini-hyper-CVD for patients with relapsed or refractory Philadelphia chromosome-negative acute lymphoblastic leukemia: a phase 2 clinical trial. JAMA Oncol. 2018; 4(2): 230-234, doi: 10.1001/ jamaoncol.2017.2380, indexed in Pubmed: 28859185.

29. Kantarjian H, Ravandi F, Short N, et al. Inotuzumab ozogamicin in combination with low-intensity chemotherapy for older patients with Philadelphia chromosome-negative acute lymphoblastic leukaemia: a single-arm, phase 2 study. Lancet Oncol. 2018; 19(2): 240-248, doi: 10.1016/s1470-2045(18)30011-1, indexed in Pubmed: 29352703.

30. Kantarjian HM, DeAngelo DJ, Stelljes M, et al. Inotuzumab ozogamicin versus standard therapy for acute lymphoblastic leukemia. N Engl J Med. 2016; 375(8): 740-753, doi: 10.1056/NEJMoa1509277, indexed in Pubmed: 27292104.

31. Jabbour EJ, DeAngelo DJ, Stelljes M, et al. Efficacy and safety analysis by age cohort of inotuzumab ozogamicin in patients with relapsed or refractory acute lymphoblastic leukemia enrolled in INO-VATE. Cancer. 2018; 124(8): 1722-1732, doi: 10.1002/ /cncr.31249, indexed in Pubmed: 29381191.

32. Oostrum Iv, Su Y, Heeg B, et al. Quality-adjusted life years (QALY) for inotuzumab ozogamicin vs standard of care for relapsed/refractory acute lymphoblastic leukemia (R/R ALL). J Clin Oncol. 2017; 35(15 Suppl): e18506-e18506, doi: 10.1200/ /jco.2017.35.15 suppl.e18506.

33. Assi R, Kantarjian H, Ravandi F, et al. Inotuzumab ozogamicin (IO) combined with mini-hyper-CVD as salvage therapy for patients (pts) with R/R acute lymphoblastic leukemia (ALL). J Clin Oncol. 2017; 35(15 Suppl): 7025-7025, doi: 10.1200/jco.2017.35.15_suppl.7025.

34. Kebriaei P, Cutler C, de Lima M, et al. Management of important adverse events associated with inotuzumab ozogamicin: expert panel review. Bone Marrow Transplant. 2018; 53(4): 449-456, doi: 10.1038/s41409-017-0019-y, indexed in Pubmed: 29330398.

35. Mohty M, Malard F, Abecassis M, et al. Sinusoidal obstruction syndrome/veno-occlusive disease: current situation and perspectives a position statement from the European Society for Blood and Marrow Transplantation (EBMT). Bone Marrow Transplant. 2015; 50(6): 781-789, doi: 10.1038/bmt.2015.52, indexed in Pubmed: 25798682.

36. Dalle JH, Giralt SA. Hepatic veno-occlusive disease after hematopoietic stem cell transplantation: risk factors and stratification, prophylaxis, and treatment. Biol Blood Marrow Transplant. 2016; 22(3): 400-409, doi: 10.1016/j.bbmt.2015.09.024, indexed in Pubmed: 26431626.

37. Rajvanshi P. Hepatic sinusoidal obstruction after gemtuzumab ozogamicin (Mylotarg) therapy. Blood. 2002; 99(7): 2310-2314, doi: 10.1182/blood.v99.7.2310. 